\title{
EFFECTS OF PLANT GROWTH REGULATORS ON SHOOT MULTIPLICATION AND ROOT INDUCTION OF CASSAVA VARIETIES IN VITRO CULTURE
}

\author{
DEDEN SUKMADJAJA ${ }^{1 *}$ and HERNI WIDHIASTUTI ${ }^{2}$ \\ ${ }^{1}$ Indonesian Center for Agricultural Biotechnology and Genetic Resources Research and Development, \\ Jl. Tentara Pelajar No.3A, Bogor, Indonesia 16111 \\ 2 SEAMEO BIOTROP, Jl. Raya Tajur Km.6, PO Box 116, Bogor, Indonesia
}

\begin{abstract}
A study on propagation of three superior cassava (Manihot esculenta Crant) varieties i.e. Darul Hidayah, Malang-6 and Adira-4 through tissue culture technique was conducted at the Tissue Culture Lab of SEAMEO BIOTROP, Bogor. The objective of the experiment was to study effect of plant growth regulators on in vitro propagation, which can be used in cassava micropropagation protocol. Plant materials used were auxiliary shoots of a stem node. The experiment consisted of (i) shoot multiplication, (ii) roots induction, and (iii) acclimatization. The multiple shoot regeneration was observed by using Murashige \& Skoog (MS) basal media supplemented with $0,0.1,1.0$ and $5.0 \mathrm{mg} / \mathrm{L}$ of benzylaminopurine (BAP) combined with 0.0 , 0.1 and $1.0 \mathrm{mg} / \mathrm{L}$ of thidiazuron. The root induction was observed by using 0.1 and $1.0 \mathrm{mg} / \mathrm{L}$ of IBA and NAA. The resulting plantlets were transplanted into plastic polybags containing soil mixed with organic fertilizer (1:1) covered with plastic sheets and transferred to a greenhouse. The result of the study showed that the highest number of shoots for Darul Hidayah, Malang-6 and Adira-4 varieties were 4.93 shoots treated with BAP $1 \mathrm{mg} / \mathrm{L}+$ thidiazuron $0.1 \mathrm{mg} / \mathrm{L}, 4.20$ shoots at BAP media of $1 \mathrm{mg} / \mathrm{L}$, and 7.20 shoots at the media of BAP $1 \mathrm{mg} / \mathrm{L}+$ thidiazuron $0.1 \mathrm{mg} / \mathrm{L}$ respectively. The highest number of nodes produced was 2.9 nodes for Darul Hidayah at BAP $5 \mathrm{mg} / \mathrm{L}, 5.13$ nodes for Malang-6 at BAP $0.1 \mathrm{mg} / \mathrm{L}$, and 6.18 nodes for Adira- 4 at BAP $5 \mathrm{mg} / \mathrm{L}+$ thidiazuron $1 \mathrm{mg} / \mathrm{L}$. The utilization of auxin IAA or NAA could induce and accelerate the growth of roots which finally could increase the success of acclimatization process. With an average of four multiplication factors of each culture period, the potency of each cassava shoot propagated through tissue culture could produce around 37000 plants/year.
\end{abstract}

Key words: Manihot esculenta, shoot multiplication, root induction, BA, thidiazuron, IBA, NAA

\footnotetext{
* Corresponding author:
} 
In Vitro Mass Propagation System of Superior Cassava Clones - Deden Sukmadjaja et al.

\section{INTRODUCTION}

Cassava (Manihot esculenta Crantz) is one of the food crops as a source of carbohydrates. In addition, cassava has a purpose used not only as a source of carbohydrates but also as raw materials for industry, cosmetics, feed and energy. As a raw material for industry, cassava could be processed into tapioca, Glucose and Fructose syrup, Citric Acid, Monosodium Glutamate, plywood, maltose, sorbitol and ethanol (Sani 2006). Meanwhile, with the increasing world prices of gasoline, cassava has now become the second source of bioethanol for premium mixture.

In developing cassava production for agro-industry, the government of Indonesia has issued regulations among others to optimize and to use genetic sources from the available varieties and clones of cassava. A few superior cassava varieties such as Darul Hidayah, Adira and Malang could produce 22-49 ton/ha fresh root crop. It has been reported that the productivity of Darul Hidayah could reach 102 ton/ha fresh root crop. The need of plant shoots exploited on a large scale will be difficult to fulfill using conventional propagation. Cassava plant materials are commonly derived from vegetative propagation using stem cuttings. Presently tissue culture technology is used for mass propagation of plant materials.

In vitro propagation of cassava has been conducted either with shoots multiplication method or somatic embryogenesis. Somatic embryogenesis was proposed as an alternative for mass cassava propagation (Raemakers et al 1993; Mathews et al. 1993; Konan et al. 1994; Ma and Xu, 2002). However, it has not been really applied for large scale propagation because the frequency of plant regeneration from cassava somatic embryos is usually low. Shoot multiplication method is the simplest and the safest method if observed from the point of genetic stability. This method becomes the most commonly used in the initiation step of plant propagation experiment.

Many authors such as Kartha et al. (1974) and Konan et al. (1997) explored the possibility to multiply cassava using in vitro microcuttings. Nodal explants onto solid media provide an average of 3 to 4 microcuttings in 2 to 3 months.

The objective of this study was to investigate the effects of plant growth regulators on plant regeneration of three cassava varieties in media culture.

\section{MATERIALS AND METHOD}

A study was conducted at the Tissue Culture Laboratory of Bioresources Management Center (BrMC), SEAMEO BIOTROP Bogor. The experiment was conducted to observe the effects of several concentrations of BAP combined with several concentrations of thidiazuron on multiple shoot formation and of auxin (IAA and NAA) on rooting formation.

Explant source: Plant materials applied this research were the auxiliary shoots derived from stem nodes of superior cassava clones, i.e. Darul Hidayah, Malang and Adira. Isolated auxiliary shoots as explant sources were sterilized by soaking in the detergent solution for $15 \mathrm{~min}$. Then the explants were rinsed and soaked in $2 \mathrm{~g} / \mathrm{L}$ of 
both fungicide and herbicide solution for $2 \mathrm{hrs,} \mathrm{respectively.} \mathrm{The} \mathrm{soaked} \mathrm{explants} \mathrm{were}$ rinsed with distilled water three times, then soaked in $2 \% \mathrm{Na}$-hypochlorite solution for $30 \mathrm{~min}$. Explants were rinsed again by distilled water which contained $50 \mathrm{mg} / \mathrm{L}$ ascorbate acid for $10 \mathrm{~min}$. Explants ranging in size from 2 to $3 \mathrm{~mm}^{2}$ were cut aseptically without damaging the apical dome (shoots growth spot).

Culture medium and condition: The auxiliary shoot explants were inoculated onto sterilized solid basal MS medium (Murashige \& Skoog's 1962) supplemented with different concentrations and combinations of different plant growth regulators.

Shoot initiation medium: Aseptically explants were inoculated onto initiation shoot MS media i.e. supplemented with $30 \mathrm{~g} / \mathrm{L}$ sucrose and $100 \mathrm{mg} / \mathrm{L}$ polyvinyl pirolidone (PVP).

Shoot regeneration and multiplication medium: Explants which have been planted in initiation media for 1-2 weeks were transferred into regeneration and shoot multiplication media. The regeneration and multiplication medium was used with MS basal media supplemented with $30 \mathrm{~g} / \mathrm{L}$ sucrose, $80 \mathrm{mg} / \mathrm{L}$ adenine sulfate and different range of $\operatorname{BAP}(0,0.1,1,5 \mathrm{mg} / \mathrm{L})$ combined with thidiazuron $(0.0,0.1$ and $1.0 \mathrm{mg} / \mathrm{L})$. As long as the explants were in these media, they were sub cultured into the same media every 2 weeks within 4-6 weeks.

Rooting medium: Elongated micro shoots on shoot regeration media were excised and transferred to MS basal media supplemented with $30 \mathrm{~g} / \mathrm{L}$ sucrose, $2 \mathrm{~g} / \mathrm{L}$ activated carbon (charcoal) and two different concentrations of IAA and NAA (0.1 and $1.0 \mathrm{mg} / \mathrm{L}$ ) either individually.

Environmental condition: The $\mathrm{pH}$ of the medium was adjusted to 5.8 before gelling with Agar $(8 \mathrm{~g} / \mathrm{L})$ and prior to autoclaving for $15 \mathrm{~min}$ at $120^{\circ} \mathrm{C}$ and at $15 \mathrm{lbs}$ psi pressure. Sugar was added at the concentration of $30 \mathrm{gr} / \mathrm{L}$. Medium of $25 \mathrm{ml}$ was dispensed into the culture jar and plugged with autoclavable plastic cap. All the cultures were incubated in a growth room with a 16 hour photoperiod (cool, white fluorescent light -1000-1500 lux) and the temperature was maintained at $25 \pm 3^{\circ} \mathrm{C}$ with $70-80 \%$ relative humidity in the culture room. Each treatment consisted of 10 replicates and repeated three times.

Acclimatization and transfer of plantlets to soil: Plantlets with well-developed roots were removed from the culture medium. The roots were washed gently under running tap water and transferred to plastic pots (polybag) for hardening which contain mixed soil and manure (1:1). The harden plantlets in the plastic polybag were covered with transparant polyethylene sheets (for about 15 days) to maintain high humidity and were kept under shade in a net house for further growth and development.

Potential of Cassava Plant Production: The calculation of the potential number of cassava plants produced through tissue culture followed the formulation of Pennell (1987):

$$
y=A^{n} \times B \times F 1 \times F 2 \times F 3
$$

Where: $\mathrm{y}=$ number of plantlet/plants that could be produced

$\mathrm{A}=$ number of shootss produced at each subculture period (multiplication factor) 


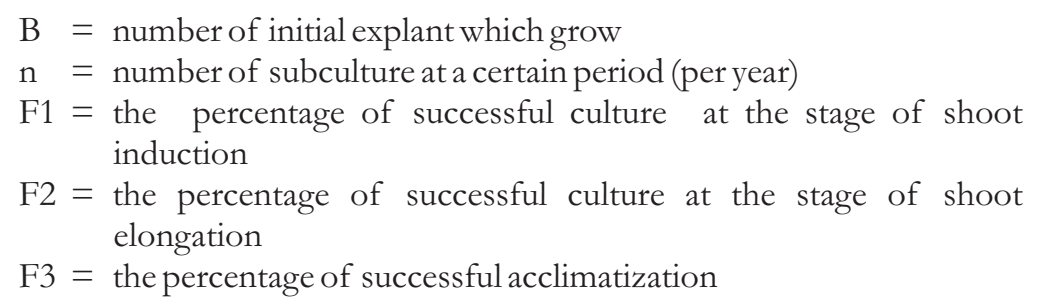

Experimental Design: Experiments were set up in a Completely Randomized Design (CRD) and each experiment usually had 10 replicates and was repeated three times. 10 explants were used per treatment in each replication. Observations were recorded on the percentage of shoots, number of shoots or nodes per explant, shoot length, numberof roots per shoot and root length respectively. Statistical analysis was limited to the calculation of standard errors of means.

\section{RESULTS AND DISCUSSION}

\section{Shoot initiation from source of explants}

The first step of shoot initiation, after one week explants were cultured on initiation media where var. Darul Hidayah produced the highest number of aseptically explants compared to the other four varieties. This is assumed to be related to the source of explants. The source of Darul Hidayah explants was taken from the green house which has low contamination due to controlled sanitation and environmental condition compared to the two other sources of explants which were taken from the field.
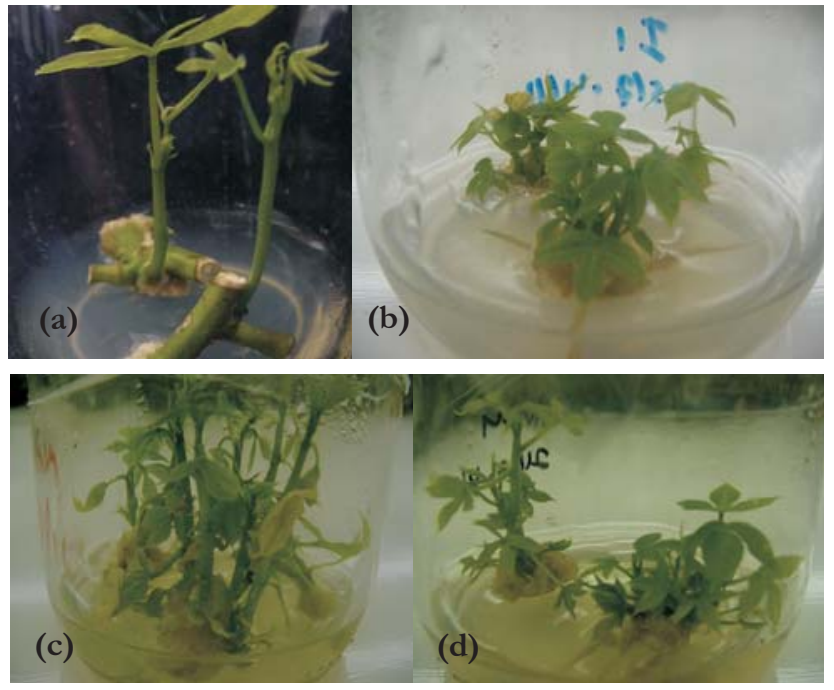

Figure1. (a) Auxiliary shoots on MS shoot induction media, (b-d) Shoots of three cassava varieties on multiplication media: var. Darul Hidayah, var. Malang-6, and var. Adira-4, respectively. 
Auxillary shoot will appear after one-week old explants were cultured on MS shoot induction media supplemented with $30 \mathrm{~g} / \mathrm{L}$ sucrose and $100 \mathrm{mg} / \mathrm{L}$ polyvinyl pirolidone (PVP) (Fig. 1a). PVP was used to inhibit necrosis of the plant tissues which were always found in woody plants according to Zdravkovic et al, 2004. The growth rate of shoot elongation with the best visual appearance was shown by Adira-4 and Darul Hidayah, while Malang-6 showed a lower growth rate of its shoot elongation. In general, shoot induction and elongation occurred after the explants were one-week old and cultured on MS media. At the age of 4 weeks the shoots had between 3-4 nodes and sufficient enough to be sub-cultured on propagation media.

\section{The Effect of Media Composition on Shoot and Root Regeneration}

Among three cassava varieties, Adira-1 was not used because most of the explants were contaminated after sub-cultured on regeneration and multiplication media. Two steps of in vitro experiments were conducted i.e. shoot multiplication and root induction. Another activity is acclimatization of plantlet in the green house.

The experimental results of the role of BAP and thidiazuron on the number shoots produced on regeneration and multiplication media are shown on Table 1. All of BAP and thidiazuron concentrations examined on Darul Hidayah and Adira-4 showed to produce an average of higher number of shoots compared to the non plant regulators media (control). On the other hand, Malang-6 explant produced higher number of shoots only on $1 \mathrm{mg} / \mathrm{L} \mathrm{BAP}$ and 0.1 thidiazuron compared to the control media. BAP could encourage cell division which stimulates formation of multiply shoots. According to $\mathrm{Lu}(1993)$ the addition of thidiazuron in media containing BAP could increase the explant ability to produce shoots. In perennial woody plants among others Prunus and Rhododendron, thidiazuron could stimulate the formation of shoots. Kerns and Meyer (1986) reported that a good result was obtained at the stage of Acer shooting by using combination of BAP and thidiazuron.

The highest shoot number of Darul Hidayah produced was about 4.93 shoots on media supplemented of $1 \mathrm{mg} / \mathrm{L}$ BAP combined with $1 \mathrm{mg} / \mathrm{L}$ thidiazuron. The use of high concentration of $5 \mathrm{mg} / \mathrm{L}$ BAP without thidiazuron resulted in high number of shoots (4.80 shoots). Adira- 4 has a better response and produce the average number of shoots compared to the other two varieties in all treatments examined. The average highest number of shoots of Adira- 4 was about 7.20 shoots on media containing $1 \mathrm{mg} / \mathrm{L} \mathrm{BAP} \mathrm{combined} \mathrm{with} 0.1 \mathrm{mg} / \mathrm{L}$ thidiazuron. The number of shoots decreased without addition of thidiazuron. The addition of thidiazuron at low concentration $(0.1 \mathrm{mg} / \mathrm{L})$ tended to increase the number of shoots produced. The average number of Malang- 6 shoots produced was lower than of the two varieties at all similar treatments. The highest number of shoots (4.20) was produced when treated with BAP $1 \mathrm{mg} / \mathrm{L}$.

The effects of growth regulator BAP and thidiazuron on the lenght of shoots are shown on Table 2. The highest lenght of shoots of Malang- 6 were $4.33 \mathrm{~cm}$ obtained on media without plant growth regulator. No significant measurable effect of BAP and thidiazuron were obtained on lenght of Malang- 6 shoots. Meanwhile, on Darul Hidayah, the use of BAP at low concentration $(0.1 \mathrm{mg} / \mathrm{l})$ with or without the addition of thidiazuron at low concentration $(0.1 \mathrm{mg} / \mathrm{l})$ resulted in higher growth of 
shoots compared to the other treatments. On the other hand the highest growth of shoots on Adira- 4 was obtained if treated with BAP at $5 \mathrm{mg} / \mathrm{l}$ concentration with or without thidiazuron, i.e. between 3.13-4.19 cm (Table 2). A high growth of shoots was also observed in media containing thidiazuron $1 \mathrm{mg} / 1 \mathrm{combined}$ with or without BAP $1 \mathrm{mg} /$, i.e. 3.44 and 3.66, respectively. Nodal explants with axillary meristems derived from aseptically grown seedlings or stem cuttings were used to initiate a round compact bulb-like structure on MS medium containing $10 \mathrm{mg} / 1 \mathrm{BAP}$. This latter structure, when cultured on MS medium supplemented with $0.1 \mathrm{mg} / 1 \mathrm{NAA}, 1 \mathrm{mg} / 1$ $\mathrm{BAP}$ and $0.1 \mathrm{mg} / 1 \mathrm{GA}_{3}$, produced multiple shoots. Rooting of regenerated shoots exceeded $95 \%$ in phytohormone-free MS medium. (Konan et al. 1997). Cytokinin could interact with other growth regulators to stimulate the vegetative growth of plants (Maxwell \& Keiber 2004). In the plant physiology process, cytokinin influences cell division in order to broaden the area of the tissues and plantlet height (Davies 2004).

Table 1. The effect of BAP combined with thidiazuron in MS media on the shoot number of Darul Hidayah, Malang- 6 and Adira-4, 30 days after planting

\begin{tabular}{lccc}
\hline & & Number of shoots & \\
Plant Growth regulator $(\mathrm{mg} / \mathrm{l})$ & Darul Hidayah & Malang-6 & Adira-4 \\
\cline { 2 - 3 } & $2.07 \pm 0.21$ & $2.79 \pm 0.30$ & $3.00 \pm 0.70$ \\
\hline Without Plant Growth regulator & $3.93 \pm 1.02$ & $3.44 \pm 1.61$ & $6.20 \pm 1.30$ \\
BAP 0 + Thi 0.1 & $2.87 \pm 1.30$ & $1.59 \pm 0.45$ & $5.50 \pm 1.29$ \\
BAP 0 + Thi 1 & $2.20 \pm 0.45$ & $2.25 \pm 0.58$ & $4.20 \pm 0.84$ \\
BAP 0.1 & $3.06 \pm 0.90$ & $2.86 \pm 1.07$ & $3.40 \pm 0.89$ \\
BAP 0.1 Thi 0.1 & $3.60 \pm 1.14$ & $2.71 \pm 0.90$ & $3.60 \pm 1.14$ \\
BAP 0.1 + Thi 1 & $4.75 \pm 1.69$ & $4.20 \pm 0.86$ & $6.41 \pm 1.52$ \\
BAP 1 & $4.20 \pm 1.00$ & $2.35 \pm 1.44$ & $7.20 \pm 3.27$ \\
BAP 1 + Thi 0.1 & $4.93 \pm 1.18$ & $2.35 \pm 0.91$ & $6.00 \pm 0.81$ \\
BAP 1 Thi 1 & $4.80 \pm 1.12$ & $2.15 \pm 0.48$ & $5.40 \pm 2.08$ \\
BAP 5 & $3.34 \pm 0.63$ & $2.45 \pm 0.58$ & $5.20 \pm 1.93$ \\
BAP 5 + Thi 0.1 & $3.48 \pm 0.87$ & $2.35 \pm 0.59$ & $3.67 \pm 1.16$ \\
BAP 5 Thi 1 & & & \\
\hline
\end{tabular}

Note: Means are calculated by standard errors

In general, the number of nodes produced in Malang- 6 and Adira- 4 varieties was higher compared to Darul Hidayah. In Malang- 6 the use of media with or without low concentration of BAP combined or not with thidiazuron $0.1 \mathrm{mg} / \mathrm{L}$ produced higher number of nodes compared to other treatments (3.98-4.61 nodes). In Adira-4, the use of thidiazuron $1 \mathrm{mg} / \mathrm{l}$ with or without addition of BAP produced high number of nodes, except for BAP $0.1 \mathrm{mg} / 1$ + thidiazuron $1 \mathrm{mg} / 1$ (4.83-6.18 nodes). In Darul Hidayah, the highest number of nodes was obtained if treated with high concentration of BAP combined with or without thidiazuron, i.e. between 2.49-2.90 nodes (Table 3). According to Mingxia et al., 2011, the cytokinin N-benzyladenine (BA) (02.0 $\left.\mathrm{mg} \mathrm{l}^{-1}\right)$ 
was effective on cassava shoot regeneration. Konan et. al. (1997) has conducted mass propagation system of some cassava cultivars through auxiliary shoots multiplication and stem nodes which showed that the addition of BAP on basal MS media was more efficient if compared to the addition of other kinds of cytokinin. The effectiveness on organogenesis was different based on different based on different cytokinins and in combination with auxins. Benzyladenine and thidiazuron stimulated more shoot organogenesis than kinetin and $\mathrm{N}$-isopentenyladenine (Ma 1998).

Table 2. The effect of growth regulator in MS media on the lenght of cassava shoot var. Hidayah, Malang-6 and Adira- 4 at 30 days after planting.

\begin{tabular}{|c|c|c|c|}
\hline \multirow{2}{*}{ Plant Growth regulator (mg/l) } & \multicolumn{3}{|c|}{ Lenght of shoots (cm) } \\
\hline & Darul Hidayah & Malang-6 & Adira-4 \\
\hline Without Plant Growth regulator & $1.50 \pm 0.68$ & $4.33 \pm 1.29$ & $1.05 \pm 0.37$ \\
\hline BAP $0+$ Thi 0.1 & $2.54 \pm 0.71$ & $2.18 \pm 0.98$ & $2.77 \pm 0.40$ \\
\hline BAP $0+$ Thi 1 & $2.16 \pm 1.52$ & $2.31 \pm 1.19$ & $3.66 \pm 0.40$ \\
\hline BAP 0.1 & $3.85 \pm 1.49$ & $2.17 \pm 1.54$ & $1.80 \pm 0.82$ \\
\hline BAP $0.1+$ Thi 0.1 & $3.90 \pm 1.50$ & $2.36 \pm 0.92$ & $1.11 \pm 0.39$ \\
\hline BAP $0.1+$ Thi 1 & $1.44 \pm 0.69$ & $2.65 \pm 0.83$ & $1.02 \pm 0.33$ \\
\hline BAP 1 & $1.61 \pm 0.76$ & $2.69 \pm 0.87$ & $2.17 \pm 0.47$ \\
\hline BAP $1+$ Thi 0.1 & $1.61 \pm 0.45$ & $1.60 \pm 1.52$ & $2.61 \pm 1.16$ \\
\hline BAP $1+$ Thi 1 & $2.26 \pm 0.75$ & $2.06 \pm 1.16$ & $3.44 \pm 0.58$ \\
\hline BAP 5 & $2.04 \pm 0.28$ & $1.24 \pm 0.44$ & $3.13 \pm 1.09$ \\
\hline BAP $5+$ Thi 0.1 & $1.14 \pm 0.24$ & $1.73 \pm 0.73$ & $4.19 \pm 1.85$ \\
\hline BAP $5+$ Thi 1 & $1.75 \pm 0.20$ & $1.61 \pm 0.45$ & $3.78 \pm 1.25$ \\
\hline
\end{tabular}

Note: Means are calculated by standard errors

Marked differences were observed among the three varieties in the auxin requirements for root induction (Table 4). Darul Hidayah and Adira-4 showed increase of both root number and length resulted from addition of IAA to the nutrient media. No significantly effect of IAA and NAA were obtained on number and lenght of root in Malang-6. The length of roots of Darul Hidayah culture showed the highest growth compared to Malang-6 and Adira-4. In Darul Hidayah, the use of IAA and NAA at the same concentrations did show a significant difference in the number of roots (Table 4). The use of NAA relatively produced higher number of roots compared with IAA. On the contrary, the use of IAA on Malang- 6 produced slightly higher number of roots compared to the use of NAA. While in Adira-4, the use of IAA (01 and $1 \mathrm{mg} / \mathrm{l}$ ) gave a significantly different result compared to the use of NAA $0.1 \mathrm{mg} / \mathrm{l}$. Ogburia (2003) has conducted a faster propagation on a number of cassava cultivars with $90 \%$ efficiency by using MS media of $0.1 \mathrm{mg} / 1 \mathrm{NAA}$ and $0.05 \mathrm{mg} / \mathrm{l}$ BAP.

The use of $0.1-1.0 \mathrm{mg} / \mathrm{L}$ IAA in rooting media of Darul Hidayah and Adira-4 produced longer roots compared to the treatment with NAA. The longest root was produced in Darul Hidayah treated with IAA $1 \mathrm{mg} / 1(5.43 \mathrm{~cm})$, and for Adira-4 treated 
with IAA $0.1 \mathrm{mg} / 1(3.23 \mathrm{~cm})$. Meanwhile, the longest root of Malang- 6 was produced if treated with NAA $0.1 \mathrm{mg} / 1$, i.e. $2.37 \mathrm{~cm}$ (Table 5, Fig. 2 (a-c). Mingxia et al,(2011) reported the auxin $\alpha$-naphthalene acetic acid (NAA) $\left(02.0 \mathrm{mg} \mathrm{l}^{-1}\right)$ proved to be effective on cassava root development. Aladele and Kuta (2008) reported that the growth rate of cassava plantlet is significantly different on various genotypes and growth environment.

In acclimatization stage, rooted shoots were transplanted in the green house for hardening and their survival rate was $90 \%$ under the field condition (Fig. 3).

Table 3. The effect of growth regulator in MS media on the number of cassava nodes in Darul Hidayah, Malang- 6 and Adira- 4 at 30 days after planting

\begin{tabular}{|c|c|c|c|}
\hline \multirow{2}{*}{ Plant Growth regulator $(\mathrm{mg} / \mathrm{l})$} & \multicolumn{3}{|c|}{ Number of nodes } \\
\hline & Darul Hidayah & Malang-6 & Adira-4 \\
\hline Without Plant Growth regulator & $2.10 \pm 0.22$ & $4.61 \pm 0.06$ & $2.53 \pm 1.52$ \\
\hline BAP $0+$ Thi 0.1 & $2.20 \pm 0.65$ & $4.78 \pm 1.42$ & $4.65 \pm 0.30$ \\
\hline BAP $0+$ Thi 1 & $1.23 \pm 0.28$ & $3.44 \pm 1.24$ & $5.76 \pm 0.76$ \\
\hline BAP 0.1 & $2.48 \pm 0.84$ & $5.13 \pm 1.04$ & $2.56 \pm 1.11$ \\
\hline BAP $0.1+$ Thi 0.1 & $1.77 \pm 0.84$ & $3.98 \pm 1.09$ & $2.70 \pm 1.36$ \\
\hline BAP $0.1+$ Thi 1 & $1.22 \pm 0.48$ & $3.33 \pm 0.30$ & $2.64 \pm 0.43$ \\
\hline BAP 1 & $2.04 \pm 0.58$ & $4.08 \pm 0.86$ & $3.92 \pm 0.90$ \\
\hline BAP $1+$ Thi 0.1 & $1.83 \pm 0.63$ & $3.23 \pm 1.82$ & $4.09 \pm 1.91$ \\
\hline BAP $1+$ Thi 1 & $2.21 \pm 0.58$ & $3.47 \pm 1.51$ & $4.83 \pm 0.96$ \\
\hline BAP 5 & $2.90 \pm 0.50$ & $2.86 \pm 0.42$ & $3.75 \pm 0.72$ \\
\hline BAP $5+$ Thi 0.1 & $2.49 \pm 0.37$ & $3.43 \pm 0.93$ & $4.52 \pm 0.62$ \\
\hline BAP $5+$ Thi 1 & $2.85 \pm 0.43$ & $3.21 \pm 0.83$ & $6.18 \pm 3.48$ \\
\hline \multicolumn{4}{|c|}{ Note: Means are calculated by standard errors } \\
\hline \multicolumn{4}{|c|}{$\begin{array}{l}\text { Table 4. The effect of auxin growth regulator in MS media on the number of cassava roots of Darul Hidayah, } \\
\text { Malang- } 6 \text { and Adira- } 4 \text { at } 15 \text { days after planting. }\end{array}$} \\
\hline \multirow{2}{*}{ Plant Growth regulator $(\mathrm{mg} / \mathrm{l})$} & \multicolumn{3}{|c|}{ Number of roots } \\
\hline & Darul Hidayah & Malang-6 & Adira-4 \\
\hline IAA 0.1 & $4.40 \pm 1.42$ & $2.30 \pm 1.77$ & $3.60 \pm 1.51$ \\
\hline IAA 1 & $3.70 \pm 0.89$ & $3.30 \pm 2.06$ & $4.30 \pm 1.57$ \\
\hline NAA 0.1 & $4.86 \pm 2.19$ & $2.00 \pm 1.63$ & $1.90 \pm 1.37$ \\
\hline NAA 1 & $3.80 \pm 1.92$ & $2.50 \pm 1.84$ & $3.20 \pm 2.10$ \\
\hline
\end{tabular}

Note: Means are calculated by standard errors 
BIOTROPIA Vol. 18 No. 1, 2011

Table 5. The effect of auxin growth regulator in MS media on the length of roots (cm) of Darul Hidayah, Malang- 6 and Adira- 4 at 15 days after planting.

\begin{tabular}{lccc}
\hline \multirow{2}{*}{ Plant Growth regulator $(\mathrm{mg} / \mathrm{l})$} & \multicolumn{2}{c}{ Length of roots $(\mathrm{cm})$} \\
\cline { 2 - 3 } & Darul Hidayah & Malang-6 & Adira-4 \\
\hline IAA 0.1 & $4.88 \pm 1.43$ & $0.77 \pm 0.62$ & $3.23 \pm 1.04$ \\
IAA 1 & $5.43 \pm 2.49$ & $1.88 \pm 1.55$ & $2.65 \pm 0.67$ \\
NAA 0.1 & $3.60 \pm 0.76$ & $2.37 \pm 1.55$ & $1.24 \pm 1.14$ \\
NAA 1 & $3.25 \pm 2.02$ & $1.61 \pm 0.84$ & $1.50 \pm 1.54$ \\
\hline
\end{tabular}

Note: Means are calculated by standard errors

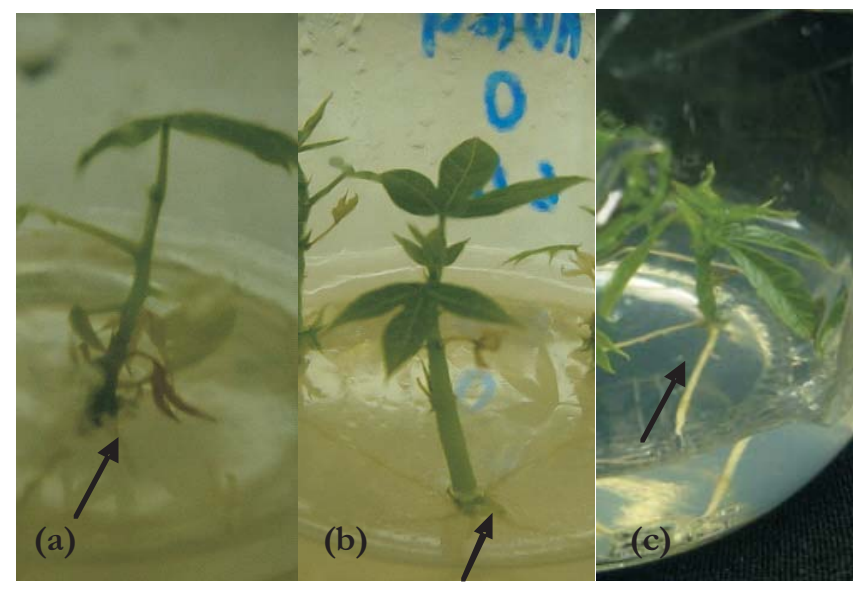

Fig. 2. The occurrence of the root growth of three cassava varieties in rooting media, (a) Darul Hidayah; (b) Malang-6; and (c) Adira-4.

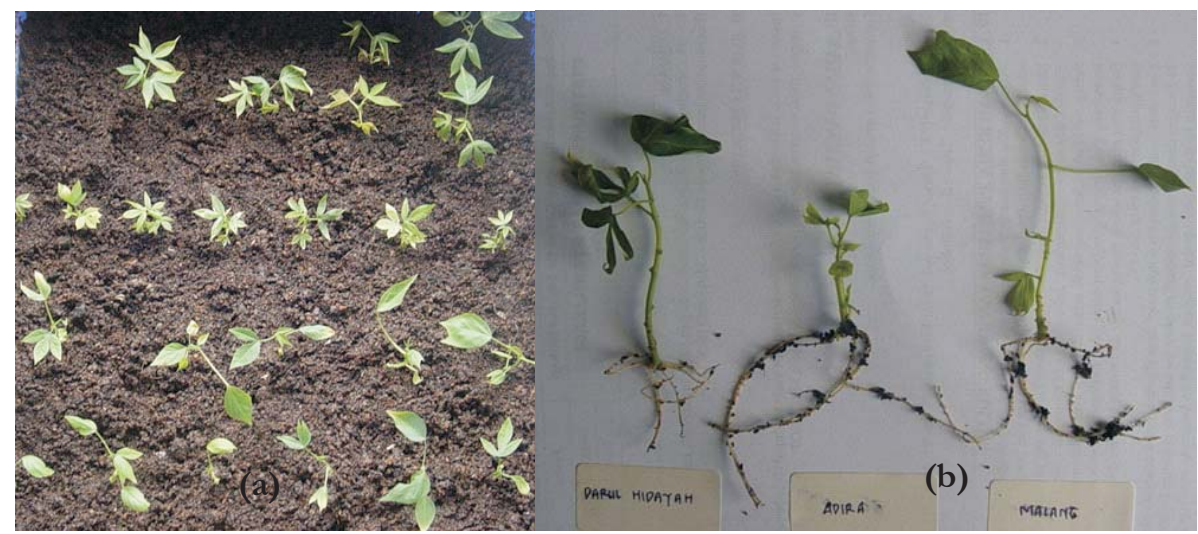

Fig. 3. Seedlings in the green house after one week old acclimatization (a) and the performace of seedling roots (b). 


\section{Potential of Cassava Plant Production}

One shoot explant (B) could produce an average of 4 (A) nodes or shoots for each culture period, with a frequency of 8 subcultures per year (n), and assumed that the success a the stage of shoot induction $(\mathrm{F} 1)=90 \%$, the success at the stage of rooting $(\mathrm{F} 2)=80 \%$, then the number of plants that could be produced per year $(\mathrm{y})$ from each shoot is as follows, using the formulation of Pennell (1987):

$$
\begin{gathered}
\mathbf{y}=\mathbf{A}^{\mathrm{n}} \times \mathbf{B} \times \mathbf{~ F} 1 \times \mathbf{~ F} \mathbf{2} \times \mathbf{F} 3 \\
4^{8} \times 1 \times 0.9 \times 0.8 \times 0.8=37748 \text { plants }
\end{gathered}
$$

If there are 10 initial shoot explants (B) available then the number of plants that could be produced is about 377.480. It should be noted that the number of plants produced is based on theoretical calculation; however, the implementation depends on some other related factors such as number of manpower and available facilities.

\section{CONCLUSIONS}

Each variety of clone cassava needed a different protocol to get optimum shoot initiation, shoot multiplication, root induction and elongation. The maximum number of axillary shoots and stem nodes of cassava var Darul Hidayah, Malang-6 and Adira-4 were obtained on shoot multiplication media containing BAP and thidiazuron at different concentrations. The use of IAA and NAA media induced and accelerated the growth of roots and increased the percentage of survival plantlet in acclimatization process. The potency of each cassava shoot could be propagated to produce about 37000 plantlets per year.

\section{ACKNOWLEDGEMENTS}

The authors are grateful to SEAMEO-BIOTROP for providing financial support and facilities. Thanks are due to the technicians of the BrMC, SEAMEO-BIOTROP Plant Tissue Culture Laboratory for their assistance.

\section{REFERENCES}

Davies PJ. 2004. The plant hormones: Their Nature, Occurrence and Function In: Davies PJ (Editor) Plant Hormones Biosynthesis, Signal Transduction, Action. Kluwer Acad Press. p 1-15

Kartha KK, Gamborg OL, Constabel F, Shyluk JP. 1974. Regeneration of Cassava plants from apical meristems. Plant Sci Lett 2: 107-13

Konan NK, Sangwan RS, Sangwan BS. 1994. Somatic embryogenesis from cultured mature cotyledons of cassava (Manihot esculanta Crantz). Plant Cell Tiss Org Cult 37: 91-102

Konan NK, Schapke C, Carcamo R, Beachy RN, Fauquet C. 1997. An efficient mass propagation system for cassava (Manihot esculenta Crantz) based on nodal explants and auxiliary shoot-derived meristems. Plant Cell Rep 16(7):444-49 
BIOTROPIA Vol. 18 No. 1, 2011

Kerns HR, Meyer MM. 1986. Tissue culture propagation of Acer x Freexmani using thidiazuron to stimulate shoot tip proliferation. Hort Sci 21(5):1209-10

Lu CY. 1993. The use of thidiazuron in tissue culture. In vitro Cell Dev Biol 29:92-96

Ma GH. 1998. Effects of cytokinins and auxins on cassava shoot organogenesis and somatic embryogenesis from somatic embryo explants. Plant Cell Tissue Org Cult 54:1-2

Ma GH, Xu QS. 2002. Induction of somatic embryogenesis and adventitious shoots from immature leaves of cassava. Plant Cell Tissue Org Cult 70:281-282

Mathews H, Schopke C, Carcamo R, Chavarriaga P, Fauquet LB. 1993. Improvement of somatic embryogenesis and plant recovery in cassava. Plant Cell Rep12: 328-33 Maxwell BB, Keiber JJ. 2004. Cytokinin Signal Transduction. In Davies, PJ (Editor) Plant Hormones Biosynthesis, Signal Transduction, Action. Kluwer Acad Press. p 321-349

Pennell D. 1987. Micropropagation in horticulture. GrowerGuide No.29. Grower Books, London

Raemakers CJJM, Schavemaker CM, Cobsen E, Visser RGF. 1993. Improvement of cyclic embryogenesis of cassava (Manihotesculenta Crant). Plant Cell Rep12: 226-229

Sani S. 2006. Kebijakan dalam strategi pengembangan ubi kayu untuk agroindustri. Dalam Prospek, Strategi, dan Teknologi Pengembangan Ubikayu untuk Agroindustri dan Ketahanan Pangan. Puslitbangtan, Bogor. Hlm: 20-28

Zdravkovic-korac S, Muhovski Y, Druort P, Calic D, Rabjevic L. 2004. Agrobacterium rhizogenes mediated DNA transfer to Aesculus hippocastonum L. and the regeneration of transformed plant hormones. Plant Cell Rep 22:698-704. 